\title{
FinTech and Financial Inclusion
}

"I dream of a Digital India where mobile and e-Banking ensures financial inclusion", Narendra Modi, 16 ${ }^{\text {th }}$ Prime Minister of India, launch of digital India week, July 1st, 2015.

\section{Baptiste Venet}

\section{Introduction: Financial Inclusion, Digital Finance and Fintech...}

In 2012, Demirguc-Kunt and al. posited that, effective and inclusive financial systems are likely to benefit poor people and other disadvantaged groups because "without inclusive financial systems, poor people must rely on their own limited savings to invest in their education or become entrepreneurs -and small enterprises must rely on their limited earnings to pursue promising growth opportunities. This can contribute to persistent income inequality and slower economic growth" (2012, p.1). Twenty years earlier, McKinnon (1973), Shaw (1973) the funding fathers of the "financial liberalization" school claimed that the development of the financial system is at the heart of the economic development process.

The share of adults owning a banking account is now 69 percent worldwide. However, about 1.7 billion adults remain unbanked, most of them living in the developing world (DemirgucKunt et al., 2017, pp. 2 and 4). The World Bank Group has therefore launched in 2017 the World Bank Universal Financial Access (UFA2020) initiative. According to this initiative, by 2020 the adults who are excluded from the formal financial system will be able to manage their financial lives by having access to a transaction account allowing them to store money and send and receive payments. The initiative is focusing on 25 countries accounting for $73 \%$ of the financially excluded, out of which 32\% are in India and China (Sapovadia, 2018). 
Why so many poor people are still financially excluded whereas financial exclusion is improving globally (Demirguc-Kunt et al., 2017)? Financial exclusion is driven by several reasons:

- First because of high costs of branches: branch footprint is small and heavily urban and opening hours might be not convenient for people leaving outside the city;

- Secondly because of high documentation requirements to open a bank account: a large share of the population cannot qualify and illiterate potential clients are often excluded;

- Thirdly because low-income clients find banks intimidating: they often consider that financial products distributed by commercial banks are not designed for them. So they might prefer more familiar and flexible informal services. Some individuals may also voluntarily decide to remain outside the formal financial system either because they do not want to deal directly with banks, or they do not perceive the advantage of accessing formal financial services because of their lack of education. These individuals will not use a system, product or service they do not understand (Ozili, 2018).

- Finally, because most banks don't want low-income clients: costs vary, most banks charge a sign-up fee, then a fixed monthly or annual fee, minimum balances, etc.

At the same time about 1.1 billion corresponding to two-thirds of unbanked adults, have a mobile phone (Demirguc-Kunt et al., 2017). As mobile phone usage expands, so could opportunities to "bank the unbanked" (Maurer, 2012). The mobile technology, and more generally the so-called "digital finance", is revolutionizing access to financial services and promotes digital financial inclusion (Lauer and Lyman, 2015, Suri, 2017). Digital finance includes financial services delivered via mobile phones, the internet, or cards. These innovative digital financial services (DFS) have been launched in at least 90 countries, including three quarters of low- and lower-middle-income countries) with more than 276 DFS providers 
and 690 million registered accounts worldwide $(49,1 \%$ in Sub-Saharan Africa, $34 \%$ in South Asia, 6,8\% in Middle East and North Africa, 5,3\% in East Asia and Pacific, 3,1\% in Latin America and the Caribbean and 1,7\% in Europe and Central Asia) in 2017 (GSMA, 2018), so encouraging millions of people to use more and more digital services rather than cash-based transactions. Digital finance is a new source of innovation in financial services. According to the optimistic view of Manyika et al. (2016), DFS could provide access to financial services to 1.6 billion people in emerging economies, especially to women who are more financially excluded. DFS can also increase the volume of new credits granted to individuals and businesses by \$2.1 trillion as well as the volume of new deposits by $\$ 4.2$ trillion. In this way, DFS would boost GDP of emerging economies by $\$ 3.7$ trillion by 2025 and generate up to 95 million new jobs (Manyika et al., 2016).

The more general concept of "financial technology," or FinTech, includes any technological innovation in the financial sector: retail banking, investment as well as innovations in financial literacy and education or crypto-currencies. Originally, it emerged from start-ups and technology companies developing user-friendly, cheap and well-suited financial products through digital channels. Fintech has now evolved toward a broad variety of technological interventions into personal and commercial finance. FinTech companies are both start-ups and established financially-oriented IT firms combining finance with information/communication technology. (Gomber et al., 2017). FinTech solutions are expected to reduce operating costs, making it profitable for providers to serve a larger range of customers. For financial-service providers, Manyika et al. (2016) predict that technology can bring up to 90 percent cost reductions with respect to physical branches. This spectacular expected gain explains why developing economies are quickly moving from traditional banking to digital finance. 
What are the consequences of digitizing finance in emerging and developing economies? What do we know about the behavioral changes in DFS users (impacts on savings, remittances, etc.) and about the changes in users' welfare and economic activity? These questions are addressed in the remainder of this chapter together with potential avenues for future researches. Section 2 reviews the expected theoretical impacts of the rise of digital finance and Fintech solutions. Section 3 presents the main existing results of papers on the impact of DFS. In section 4, we give avenues for future research. Section 5 concludes.

\section{The potentials of Digital Finance}

According to Ozili (2018) and Manyika et al. (2016), the rise of digital finance and FinTech solutions may have many positive effects. Macroeconomic consequences include:

- Raising economic growth by providing access to a large range of financial products and services to individuals and medium \& large enterprises. This enhanced access to finance may lead to a reduction of informal economy, and so improve enforcement of tax collection and compliance with labor laws. Other positive impacts relate to formal savings--as opposed to saving "under the mattress"--, financial innovation, such as P2P lending or new credit scoring methods, and new business formation, such as e-commerce.

- Improving the efficiency of the global financial system and providing better monitoring devices to regulators.

- Reducing governments spending by improving tax collection, improving the targeting of subsidies and creating efficiency gains (Manyika et al, 2016). Digital payments could reduce inefficiencies to current payment flows by eliminating leakage (governments could replace cash-based social payments and subsidy programs with targeted, direct 
payments) and by lowering transaction and administrative costs. From a microeconomic standpoint, the rise of digital finance could:

- Enhance financial inclusion (World Bank 2016, Jack and Suri 2011, 2014, 2016 , Sapovadia, 2018), especially to individuals in rural areas, who save time and money by avoiding traveling to far-off branches. DFS can also improve rural economic conditions by better connecting villagers to urban migrants (Lee and al., 2018).

- Provide affordable, responsive and secure banking services to unbanked people. Access to a safe money storage and to easy transfers encourages people to trade and save more and help them carry out basic transactions such as bill payments (electricity, water supply) and money transfers (remittances).

- Reduce operational and opportunity costs for lenders by doing business more efficiently and delivering new services, such as transfers and payments of small sums, which are sometimes impossible with traditional banking.

However, the expected benefits of digital finance require three conditions to keep customers in the market (Karlan and al., 2016). First, the cost should be low (Ozili, 2018). Second, users should be well-informed and well-protected, as well as confident in a good-working digital system. Lauer and Lyman (2015) identify seven key risk areas in digital finance: inability to transact due to network/service downtime (interrupted and incomplete transactions, inaccessible funds, etc.), insufficient agent liquidity (customers do not have access to their own money), complex and confusing user interfaces, poor customer recourse (unclear, costly, and time-consuming procedure), nontransparent fees and other terms (lack of transparency

\footnotetext{
${ }^{1}$ The paper published in 2016 is referenced as Suri and Jack (2016).
} 
leaves consumers without a full understanding of the prices, terms, and conditions of the services they are using), fraud perpetrated on the customer, and data privacy and protection (poor understanding of new uses of personal data, etc.).

Last, digital financial services must be primarily "transformational" rather than "additive" (Porteous, 2006), meaning that unbanked people can gain access to financial services through their mobile without having a prior bank account. The promise of digital finance to "bank the unbanked" refers to the transformative model.

\section{What about impact evidence?}

The recent growth in the number of DFS worldwide and the excitement generated by these initiatives of financial inclusion have prompted the publication of several studies. Many of them assess the effects of mobile-payment (m-payment), or mobile-banking (m-banking) services-the most common digital financial services, on users. The studies have been conducted mainly ${ }^{2}$ in Africa: South Africa (Ivatury and Pickens, 2006), Uganda (Ndiwalana et al., 2011) and mainly in Kenya because of the birth of M-PESA ${ }^{3}$, the most famous DFS in the developing world.

We present the results of some research studies focusing mainly on clients' changing patterns in financial behavior (savings and remittances) and on some economic impacts (income shocks smoothing, employment and impact on poverty) of DFS.

\footnotetext{
${ }^{2}$ Mobile payment systems have also been lauched in other countries such that the Philippines, Afghanistan etc., and in a number of countries in Latin America and the Middle East.

3 "M" is for mobile, and "PESA" means money in Swahili. It was launched in 2007. M-PESA is a money transfer system operated by Safaricom, Kenya's largest cellular phone provider in the country. M-PESA allows users to exchange cash for e-money on their phones, to send e-money to other cellular phone users, and to exchange emoney back into cash. The customer does not need to have a bank account but must be registered with Safaricom.
} 


\subsection{Savings and remittances}

There is mixed evidence on the impact on DFS users' savings. Focusing on Kenya, Jack and Suri (2011) find that between 2008 and $2009^{4}$, an increasing number of M-PESA customers use it as a saving tool: from 76 percent in 2008 to 81 percent in 2009. However, 71 percent of MPESA users in 2008 and 77 percent in 2009 continue to put some money "under the mattress". Last, bank account holders save significantly more than other M-PESA user households. Hence the formal banking system and M-PESA seems to complement each other rather than compete. This is not what was suggested by Morawczynski and Pickens (2009) for who MPESA serves as a partial substitute for the formal banking system. Mbiti and Weil (2016) are using some information on the savings methods used by households. They assess that M-PESA has reduced the prevalence of informal savings (ROSCAs, savings with a group of friends, and savings entrusted to a family or friend for safekeeping) by 15 percentage points and reduced the proportion of people saving money in secret places by 30 percentage points. However, they conclude that although a significant number of survey respondents indicate that they use their M-PESA accounts as a vehicle for saving, "the analysis of aggregate data suggests that M- PESA is only rarely used for storing value for any significant period of time". Demombynes and Thegeya (2012) investigate the mobile savings phenomenon in Kenya, using data collected from a survey conducted for 6,083 individuals in 2010. They define respondents as having "MPESA savings" if they report saving a portion of income and lists M-PESA as one of the places for savings. A comparison of rates found by the survey shows that 65 percent of M-PESA users report having some savings, compared to 31 percent of those who are not M-PESA users. To explain this difference in terms of extensive and intensive margins, they compute probit

\footnotetext{
${ }^{4}$ Between 2008 and 2014, Jack and Suri (2011, 2014, and 2016) conducted five rounds of a households panel survey across Kenya.
} 
regressions where the dependent variable is the probability of saving. Results show that controlling for standard variables (gender, marital status, etc.), those who are registered MPESA users are 32 percent more likely to report having some savings ${ }^{5}$. They also assess the possible effects of M-PESA usage on sums saved. In an OLS estimation, M-PESA users are found to save significantly more than those who are not registered ${ }^{6}$. Kikulwe et al. (2014) and Johnson (2016) conducted small-scale surveys in Kenya. Kikulwe et al. (2014) conducted two surveys in the Central and Eastern provinces of Kenya and Johnson (2016) conducted a survey in 2010 and 2011 among individuals from households living in three rural districts. Kikulwe et al. (2014) find that over 40 percent of the households stated that they use their mobile money account as a savings tool in 2010. Johnson (2016) finds that most of the Mobile Money Transfers (MMT) users withdraw funds completely after receiving a transfer. It means that "by putting money in the phone, $[\ldots]$, was not coterminous with a place to "save" in the sense of building up balances but was more related to being able to move around with funds". Using a matching methodology and focusing on a panel of mobile money users in Antananarivo in Madagascar, Arestoff and Venet (2013) find no positive impact on savings for users even if 62.7 percent of users rate the impact of cash-in (deposit) on their savings as positive. They put it that users may not save more in total, but that they may save differently by using a different formal means of savings.

Let's turn to remittances. Using the 2009 FinAccess surveys, Mbiti and Weil (2016) find that almost 35 percent report that using M-PESA has increased their frequency of sending

\footnotetext{
${ }^{5}$ Using an IV strategy, they find that M-PESA registration increases the likelihood of having savings by 20 percent.

${ }^{6}$ The estimate is no more statistically significant in the IV estimation.
} 
transfers, while 31 percent report an increase in the frequency of transfers received. This is in line with what was found by Morawcyznski and Pickens (2009). At the same time, 35 percent of users claim that they sent larger transfers due to M-PESA, while 30 percent claim to have received larger transfers because of M-PESA. In contrast, 20 percent report decreases in the amount of transfers sent or received, with the remainder reporting no change in the amount of transfers received or reported. Combining the 2006 and 2009 FinAccess surveys, they build a balanced panel of 190 sub-locations surveyed in two rounds. They find a positive relationship between M-PESA adoption and frequency of sending and receiving transfers, although only the estimate of sending transfers is statistically significant. These results are robust to FE-IV estimations. Arestoff and Venet (2013) find that only the frequencies of remittances sent and received are positively affected by the use of mobile-money: neither sums of money transfers nor sums saved are impacted. They explain these results by positing that individuals change their money transfer method because the m-banking service is cheaper and safer. Jack and Suri (2014) find that in the first round (2008), the most important use was sending money for 25 percent of M-PESA users whereas it was receiving money for another 29 percent. In the third round (2010), over 90 percent of M-PESA users say they use the service to send or receive money.

So even there is mixed evidence on the impact of DFS on individual savings, various studies offer clear-cut results about the positive impact of DFS on remittances.

\subsection{Users' welfare and impact on economic activity:}

What are the main results of DFS on income shocks smoothing, employment and on poverty? Aker and Mbiti (2010) and Klapper and Singer (2014) suggest that digital payments can reduce households' exposure to risk because DFS “connect individuals to the broader economy and 
can strengthen informal insurance networks. Electronic networks allow families to expand their "community," and can help households smooth unexpected income shocks by accessing money or support from a community wider than those physically proximate" (Klapper and Singer 2014, p. 9). This is empirically confirmed by Jack and Suri (2014). Using the data on Kenyan households collected in 2008 and data collected during the follow-up surveys of the same households conducted in 2009 and 2010, they show that facing not expected idiosyncratic shocks, M-PESA users consumption is not affected, whereas non-user households face a 7 percent decrease in consumption. In her qualitative study, Morawczynski (2011) finds an increase in remittances flows. "Such an increase also occurred because MPESA made it easier for rural dwellers to make claims on resources. Some expanded their network of remitters and began to solicit "small money" from distant kin and relatives. In some cases, this cash was used to address unexpected shocks that emerged. In others, it was used to prepare for future ones" (p. 166). Masino and Niño-Zarazúa (2014) analyses a case of financial innovation in social service delivery implemented in Mexico in the context of the conditional cash transfer programme Oportunidades (recently renamed as Prospera). Oportunidades' income support was initially paid in cash at distribution points located in towns. Since 2011, all Oportunidades beneficiaries receive the transfer electronically. Their results indicate that the transition from cash to electronic payments reduced remittance reception costs, and it highlights the contribution of remittances in smoothing consumption and mitigating the effects of income shocks.

Mbiti and Weil (2016), Beck et al. (2018) and Suri and Jack (2016) are focusing on short and long-term economic impacts. Mbiti and Weil (2016) use a broad measure of employment that includes farm labor, nonfarm labor, and self-employment. Individuals are considered employed if they are actively engaged in any of these activities. They show that the use of M- 
PESA is associated with increases farm employment but that it has no impact on nonfarm employment. However, Suri and Jack (2016) find that households who experienced larger increases in M-PESA access (measured by the number of M-PESA agents within one kilometer of the household) were less likely to be working in farming or to have a secondary occupation and more likely to be working in "business or sales". Beck et al. (2018) are developing a dynamic general equilibrium model with heterogeneous firms to evaluate the effects of a mobile payment on firm-level performance and access to supplier credit in an economy characterized by credit imperfections, information asymmetries and the risk of theft. In the model, they show that the availability of mobile money reduces the incidence of theft because mobile payment secures financial transactions and could give people an access to a safe transfer mechanism. It also increases the valuation of trade credit. Calibrating the stationary equilibrium of the model to match a set of moments observed in Kenyan FinAccess survey data from 2014, they find that eliminating the use of mobile money in an environment with a theft probability of $2 \%$ translates into a macroeconomic output loss of $1.2 \%$. Then, the introduction of M-PESA seems to have a positive effect on per-capita income growth: "Comparing the estimated outcome effects of M-PESA with actual growth numbers for the Kenyan economy shows that the introduction of the M-PESA technology in 2007 can explain 10\% of the per-capita income growth between 2007 and 2013 thus pointing to quantitatively significant macroeconomic effects of mobile money technology through entrepreneurial finance" (p. 164).

Suri and Jack (2016) are focusing on the long-run impacts of Digital Finance and use the five rounds of their household panel survey to that end. The dynamic aspect of their analysis is implemented by comparing outcomes, as measured in the 2014 survey, of households that saw large increases in agent density between round 1 and round 2 with outcomes of 
households that experienced smaller increases over the same period. They find that access to M-PESA “increased per capita consumption levels and lifted 194,000 households, or $2 \%$ of Kenyan households, out of poverty" (p. 1288). However, this optimistic result is a bit tempered the conclusions of Dubus and Van Hove (2017). Using survey data collected among 3,000 Kenyan respondents, they implement a three-step probit procedure to identify the sociodemographic characteristics of, successively, the respondents who do not have access to a SIM card, have access to a SIM card but have not opened an M-PESA account, and, finally, have an M-PESA account but do not save on it. They equate financial inclusion with being able to save formally (digitally) using M-PESA. They find that the poor, the non-educated, and women do not benefit from the positive effects of M-PESA. Moreover, the problem is, by and large, bigger for the rural than for the urban population.

Last, Banerjee et al. (2016) and Muralidharan et al. (2016) are focusing on the impact of the use of Digital Finance on welfare programs and corruption. Banerjee et al. (2016) show that the use of DFS to transfer program funds for the same public works program reduced by 38 percent the program fund expenditure and by 25 percent the corruption in India. Muralidharan et al. (2016) show that biometrically authenticated cards for workers employed by a public works program reduced corruption and could enhance the ability to implement welfare programs in developing countries.

\section{Directions for future research}

The literature focuses on mobile payments, especially in Kenya, and on users' behavior and welfare. Some additional papers are dedicated either to digital money (cryptocurrencies) and block chain technologies, crowdfunding, mobile trading, etc. Gomber et al. (2017) reviews the abundant literature on three digital finance dimensions: business, technology, and 
institutions. Yet, the impacts of digital finance and FinTech on emerging and developing economies still need to be addressed. The most promising issues relate to the following topics: - The regulation of digital finance, including security aspects and customer/investor protection, such as appropriate KYC ("know your customer") transparent and concrete rules, which safeguard financial integrity and must be institutionalized (Gelb, 2016, Buku and Mazer, 2017, Karlan et al., 2016). This point, highlighted by Patwardhan (2018), also relates to systemic risk (Ozili, 2018). For instance, do we need banking licenses for DFS providers? What is the impact of digital finance on financial stability?

- The digital models designed for poor households. Karlan et al. (2016) and Gomber et al. (2017) call for research in the field of digital insurances. Using financial products based on automated weather index models with satellite data are promising instruments to hedge smallholder farmers against losses resulting from adverse climatic risks. Enabling poor people to smooth their income over time is a key element to tackle vulnerability and reduce the risk of poverty. - The influence of DFS on users' savings? The papers by Mbiti and Weil (2016) and Johnson, (2016) reveal that DFS are rarely used as a savings vehicle for any significant period of time. This surprising result can be explained by three factors. First, as it is pointed out by Dubus and Van Hove (2017), Jack and Suri's $(2011,2014,2016)$ broad definition "savings" refers to any form of money storage for more than twenty-four hours. Second, it could be that users save differently with DFS (Arestoff and Venet, 2013). Last, Karlan et al. (2016) mention the lack of advanced savings products dedicated to the poor. Identifying the most probable causes of the “digital savings puzzle” offers fruitful avenues for further research.

- The real impact of digital finance on financial inclusion. Is Digital Finance really a transformative model? According to Dubus and Van Hove (2017), the poor, the non-educated, women and the rural population do not benefit from the positive effects of M-PESA. How do 
these findings compare to the lack of impact found in randomized studies on health, education, and women's empowerment (Banerjee et al., 2015)?

\section{Conclusion}

Salampasis and Mention (2018, p. 457) summarize the role of FinTech as "to promote transparency, safety, and accountability through a secure, behavioral, cashless, cultural mindshift in terms of building a financially inclusive world, strengthening the economic and sustainable development." This quote encapsulates the world's expectations from digital finance and FinTech. However, along with high expectations of Digital Finance come the fears evoked in this chapter. Current concerns relate mainly to regulation, impact on financial stability, consumer information and protection, and product design for the poor. These challenging issues cutting across research disciplines offer promising avenues to scholarly and applied research alike. 


\section{References}

Aker, J. C., \& Mbiti, I. M. (2010), "Mobile Phones and Economic Development in Africa”, The Journal of Economic Perspectives, 24(3), 207-232,

Arestoff, F., \& Venet, B. (2013). "Learning to Walk Before you Run: Financial Behavior and Mobile Banking in Madagascar", Working paper No. DT/2013/09. Université ParisDauphine.

Banerjee, A., Duflo, E., Glennerster, R., \& Kinnan, C. (2015), "The Miracle of Microfinance? Evidence from a Randomized Evaluation", American Economic Journal: Applied Economics, vol. 7(1): 22-53.

Banerjee, A., Duflo, E., Imbert, C., Mathew, S. \& Pande, R. (2016), "E-governance, Accountability, and Leakage in Public Programs: Experimental Evidence from a Financial Management Reform in India," NBER Working Papers 22803, National Bureau of Economic Research, Inc.

Beck, T., Pamuk, H., Ramrattan, R., \& Uras, B.R. (2018), "Payment instruments, finance and development", Journal of Development Economics, vol. 133, 162-186.

Buku, M., \& Mazer, R. (2017), "Fraud in Mobile Financial Services: Protecting Consumers, Providers, and the System", Brief Note, April, CGAP.

Demombynes, G and Thegeya, A. (2012), "Kenya's Mobile Revolution and the Promise of Mobile Savings", Policy Research Working Paper 5988, The World Bank.

Demirguc-Kunt, A. \& Klapper, L. (2012), “Measuring Financial Inclusion, the Global Findex Database", The World Bank.

Demuric-Kunt, A., Klapper, L.., Singer, D., Ansar, S., \& Hesset, J. (2017), "The Global Findex Database: Measuring Financial Inclusion and the Fintech Revolution", World Bank.

Dubus, A., \& Van Hove, L. (2017), “M-PESA and financial inclusion in Kenya: of paying comes saving? HAL-01591200.

Gelb, A., (2016), "Balancing Financial Integrity with Financial Inclusion: The Risk-Based Approach to "Know Your Customer"”, Center for Global Development Policy Paper 74, Center for Global Development, Washington DC.

Gomber, P., Koch, J-A., \& Siering, M. (2017), “Digital Finance and FinTech: current research and future research directions", Journal of Business Economics, vol. 87 (5), 537-580.

GSMA (2018), "2017 State of the Industry Report on Mobile Money", London. 
Ivatury, G., \& Pickens, M. (2006). “Mobile phone banking and low-income customers: Evidence from South Africa", CGAP/The World Bank and United Nations Foundation.

Jack, W., \& Suri, T. (2011). "Mobile Money: the Economics of M-PESA", NBER Working Papers 16721, National Bureau of Economic Research, Inc.

Jack, W., \& Suri, T. (2014). “Risk Sharing and Transactions Costs: Evidence from Kenya's Mobile Money Revolution", The American Economic Review, 104(1), 183-223.

Johnson, S. (2016). "Competing Visions of Financial Inclusion in Kenya: The Rift Revealed by Mobile Money Transfer", Canadian Journal of Development Studies, 37(1), 83-100.

Karlan, D., Kendall, J., Mann, R., Pande, R., Suri, T. \& Zinman, J. (2016), “Research and Impacts of Digital Financial Services", NBER Working Papers 22633, National Bureau of Economic Research, Inc.

Kikulwe, E.M., Fischer, E. \& Qaim, M., (2014), “Mobile Money, Smallholder Farmers, and Household Welfare in Kenya", PLoS ONE 9(10): e109804.

Klapper, L., \& Singer, D. (2014), “The Opportunities of Digitizing Payments, Working paper 90305, The World Bank.

Lauer, K. \& Lyman, T. (2015), “Digital Financial Inclusion: Implications for Customers, Regulators, Supervisors, and Standard-Setting Bodies", Brief Note, February, CGAP.

Lee, J., Morduch, J., Ravindran, S., Shonchoy, A., \& Zaman, H. (2018), "Poverty and Migration in the Digital Age: Experimental Evidence on Mobile Banking in Bangladesh", Working paper.

Masino, S. \& Niño-Zarazúa, M., (2014), "Social service delivery and access to financial innovation. The impact of Oportunidades' electronic payment system in Mexico", MPRA Paper, University Library of Munich, Germany.

Mbiti, I., \& N. Weil D. (2016), "Mobile Banking: The Impact of M-PESA in Kenya", in African Successes, Volume III: Modernization and Development, ed. by Sebastian Edwards, Simon Johnson, and David N. Weil, University of Chicago Press, 247-293.

McKinnon, R. I., (1973), "Money and Capital in Economic Development", Brookings Institution, Washington, D.C.

Manyika, J., Lund, S., Singer, M., White, O., \& Berry, C. (2016). Digital Finance for All: Powering Inclusive Growth in Emerging Economies. McKinsey Global Institute. September.

Morawczynsk, O., (2011), "Examining the Adoption, Usage and Outcomes of Mobile Money Services: The Case of M-PESA in Kenya", The University of Edinburgh. 
Morawczynski, O., \& Pickens, M. (2009), “Poor People Using Mobile Financial Services: Observations on Customer Usage and Impact from M-PESA", CGAP Brief Online.

Maurer, B. (2012), "Mobile Money: Communication, Consumption and Change in the Payments Space", Journal of Development Studies, 48, 589-604.

Muralidharan, K., Niehaus, P. \& Sukhtankar, S. (2016), "Building State Capacity: Evidence from Biometric Smartcards in India," The American Economic Review, vol. 106(10), 2895-2929.

Ndiwalana, A., Morawczynski, O., and Popov, O. (2011), “Mobile Money Use in Uganda: A Preliminary Study". PHB Development report and Kurt Salmon.

Ozili, P. K. (2018), "Impact of Digital Finance on Financial Inclusion and Stability", Borsa istanbul Review, forthcoming.

Patwardhan, A. (2018), "Financial Inclusion in the Digital Age", Handbook of Blockchain, Digital Finance, and Inclusion, Volume 1, ed. by David Lee Kuo Chuen and Robert H. Deng, 57-89. Porteous, D. (2006), "The Enabling Environment for Mobile Banking in Africa", DFID, London. Salampasis, D., \& Mention, A-L., (2018), “FinTech: Harnessing Innovation for Financial Inclusion", in Handbook of Blockchain, Digital Finance, and Inclusion, Volume 2, ed. by David Lee Kuo Chuen and Robert H. Deng, 451-461.

Sapovadia, V. (2018), "Financial Inclusion, Digital Currency, and Mobile Technology", in Handbook of Blockchain, Digital Finance, and Inclusion, Volume 2, ed. by David Lee Kuo Chuen and Robert H. Deng, 361-385.

Shaw, E. S., (1973), "Financial Deepening in Economic Development", New York: Oxford University Press.

Suri, T. (2017), "Mobile Money", Annual Review of Economics, Vol. 9, 497-520.

Suri, T., \& Jack, W. (2016). "The Long-Run Poverty and Gender Impacts of Mobile Money", Science, 354(6317), 1288-1292.

World Bank (The), (2016), “World Development Report 2016: Digital Dividends", Washington. 